RFP-1299

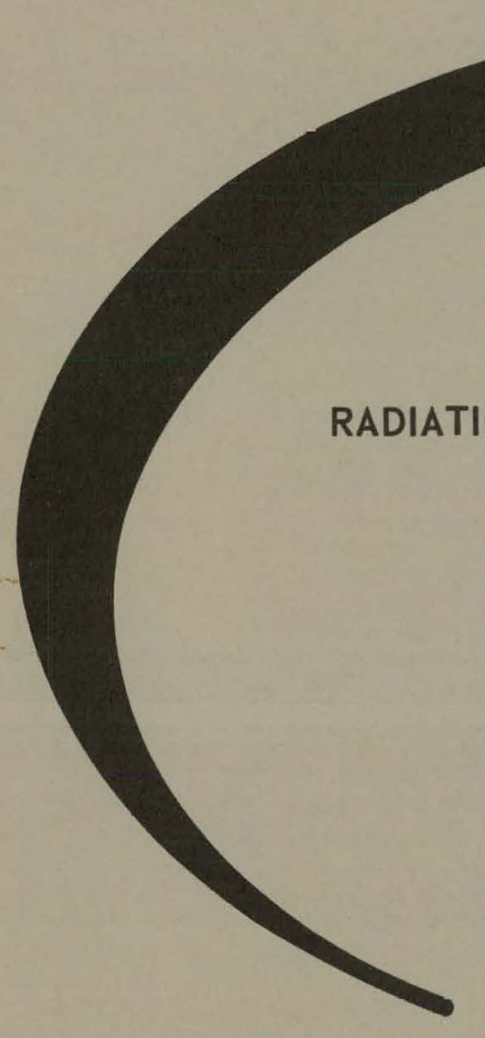

This document is intended for publication in the open literature. Extracts or references must not be published prior to such publication without the permission of the authors.

Office of Safeguards and Materials Management as part of its Program of Safeguards Research and Development

$$
\text { for }
$$

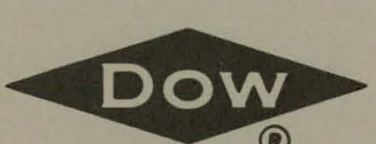

THE DOW CHEMICAL COMPANY

ROCKY FLATS DIVISION

P. O. BOX 888

GOLDEN, COLORADO 80401

U.S. ATOMIC ENERGY COMMISSION CONTRACT AT(29-1)-1106 


\section{DISCLAIMER}

This report was prepared as an account of work sponsored by an agency of the United States Government. Neither the United States Government nor any agency Thereof, nor any of their employees, makes any warranty, express or implied, or assumes any legal liability or responsibility for the accuracy, completeness, or usefulness of any information, apparatus, product, or process disclosed, or represents that its use would not infringe privately owned rights. Reference herein to any specific commercial product, process, or service by trade name, trademark, manufacturer, or otherwise does not necessarily constitute or imply its endorsement, recommendation, or favoring by the United States Government or any agency thereof. The views and opinions of authors expressed herein do not necessarily state or reflect those of the United States Government or any agency thereof. 


\section{DISCLAIMER}

Portions of this document may be illegible in electronic image products. Images are produced from the best available original document. 


\section{LEG AL NOTICE}

This report was prepared as an account of Government sponsored work. Neither the United States, nor the Commission, nor any person acting on behalf of the Commission:

A. Makes any warranty or representation, expressed or implied, with respect to the accuracy, completeness, or usefulness of the information contained in this report, or that the use of any information, apparatus, method, or process disclosed in this report may not infringe privately owned rights; or

B. Assumes any liabilities with respect to the use of, or for damages resulting from the use of any information, apparatus, method, or process disclosed in this report.

As used in the above, "person acting on behalf of the Commission" includes any employee or contractor of the Commission, or employee of such contractor, to the extent that such employee or contractor of the Commission, or employee of such contractor prepares, disseminates, or provides access to, any information pursuant to his employment or contract with the Commission, or his employment with such contractor.

Printed in the United States of America

Available from

Clearinghouse for Federal Scientific and Technical Information

National Bureau of Standards, U. S. Department of Commerce

Springfield, Virginia 22151

Price: Printed Copy $\$ 3.00$; Microfiche $\$ 0.65$ 


\section{LEGAL NOTICE}

This report was prepared as an account of Government sponsored work. Neither the United States, nor the Commission, nor any person acting on behalf of the Commission:

A. Makes any warranty or representation, expiessed ur implied, with respect to the accuracy, completeness, or usefulness of the information contalned in this report, or that the use of any information, apparatus, method, or process disclosed in this report may not infringe privately owned rights; or

B. Assumes any llabllities with respect to the use of, or for damages resulting from the use of any information, apparatus, method, or process disclosed in this report.

As used in the above, "person acting on behalf of the Commlssion" inoludeo any employee or contractor of the commission, or employee of such contractor, to the extent that such employee or contractor of the Commlssion, or employee of such contractor prepares, disseminates, or provides access to, any information pursuant to his employment or contract with the Commission, or his employment with such contractor.

\section{RADIATION CHEMISTRY OF. NITRIC ACID SOLUTIONS}

Frend J. Miner

Armen R. Kazanjian

Alan K. Brown

Paul G. Hagan

James W. Berry

for

Office of Safeguards and Materials

Management as part of its Program

of Safeguards Research and

Development

This document is intended for publication in the open literature. Extracts or references must not be published prior to such publication without the permission of the outhors.

\footnotetext{
THE DOW CHEMICAL COMPANY ROCKY FLATS DIVISION

P. O. BOX 888

GOLDEN, COLORADO 80401

U. S. ATOMIC ENERGY COMMISSION CONTRACT AT(29-1)-1106
} 


\section{A CKN OW.I. E DGMENTS}

The authors acknowledge the assistance of the Mass Spectroscopy Laboratory at Rocky Flats for gas analyses, A. L. Johnston for assistance in the chemical analyses, J. R. Seed (Rocky Flats) and W. C. Gottschall, Jr. (University of Denver) for advice and counsel, and Mound Laboratory for the ${ }^{238} \mathrm{PuO}_{2}$ microsphere. 
RFP-1299

\section{CON TEN T S}

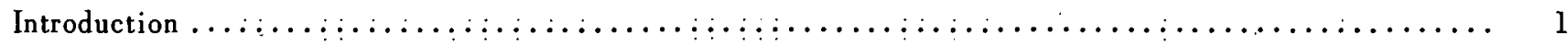

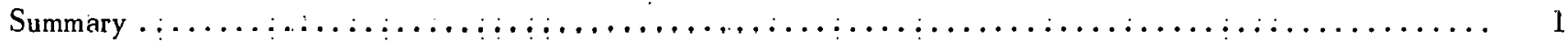

Experimental Results $\ldots \ldots \ldots \ldots \ldots \ldots \ldots \ldots \ldots \ldots \ldots \ldots \ldots \ldots \ldots \ldots \ldots$

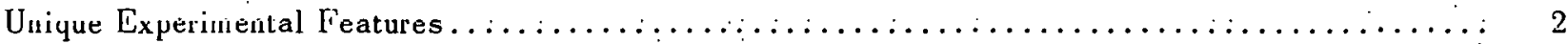

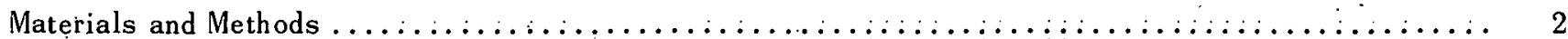

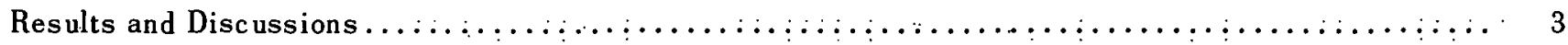

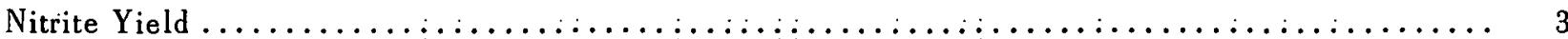

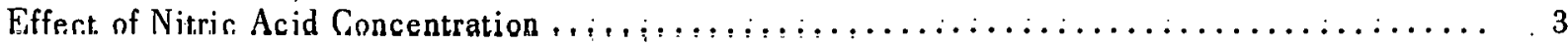

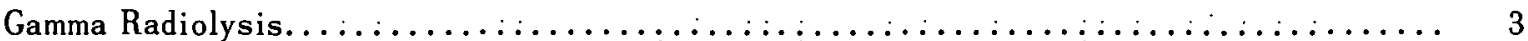

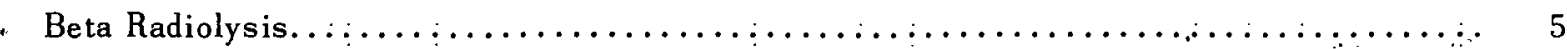

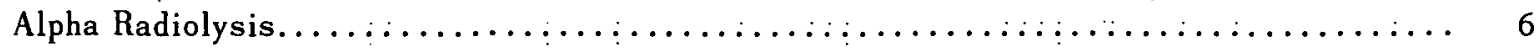

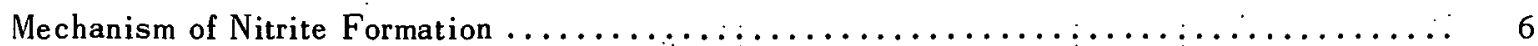

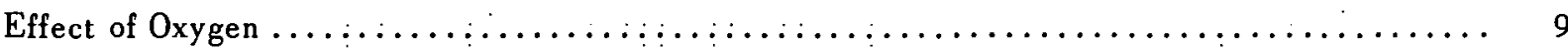

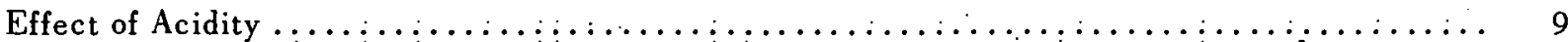

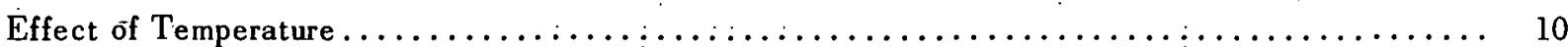

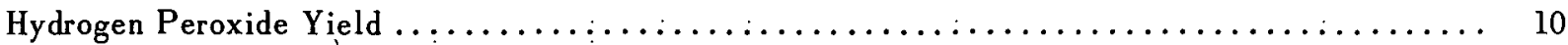

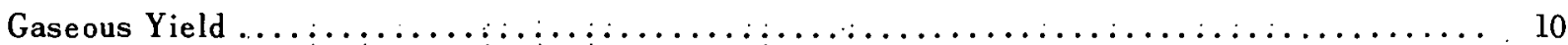

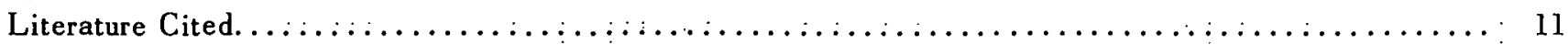

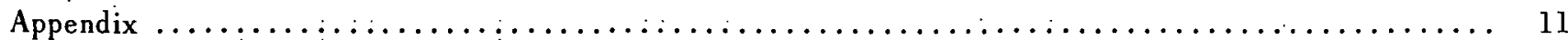


RFP-1299

\section{PREFACE}

Previous studies and experience in shipping plutonium nitrate solutions have indicated that radiation from the plutonium causes precipitale furmation and variation in the ionic form of plutonium in the solution. These both lead to instability, non-representative sampling, and inaccurate chemical analyses. To eliminate these problems. information is required on the meshanisms hy whirh radiation affects the chemical stability of plutonium in nitric acid solutions. Knowing these mechanisms, effective counter measures can be taken to minimize the effects that produce the instability.

An experimental program (INVESTIGATION OF THE RADIATION CHEMISTRY OF PLUTONIUM NITRATE SOLUTIONS) was undertaken to develop criteria for solution composition of plutonium nitrate solutions that would lead to the most stable solutions possible under conditions imposed by fuel reprocessing methods. This program was divided into two major parts: First, an investigation of the radiation chemistry of nitric acid without plutonium present to determine the radiolysis products formed that could react with plutonium; and second, an investigation of comparable nitric acid solutions with plutonium present to determine tho ohangoo in the oxidation states of the plutonium iuns in the sulution. Frun these data, possible mechanisms for the reactions involving plutonium that lead to unstable solutions could be postulated and appropriate countermeasures developed.

Budgetary restrictions forced the discontinuance of this program with only the investigation of the radiation chemistry of nitric acid, without plutonium present, being completed. It is hoped that funds become available and the remainder of the program can be completed soon. Information that would be obtained has taken on increased importance because of possible storage of plutonium in nitrate solutions for extended periods of time. 
RFP-1299

\title{
RADIATION CHEMISTRY OF NITRIC ACID SOLUTIONS
}

\author{
F. J. Miner, A. R. Kazanjian, A. K. Brown, P. G. Hagan, and J. W. Berry
}

\section{INTRODUCTION}

The radiation chemistry of the aqueous nitrate system has been the subject of much study, especially in the last decade (1-5). However, most of the investigations have been in neutral or slightly basic solutions. 'Ihe reportcd works in acidic solutions have been by Savel'ev, et al, (6), Mahlman (7), and Vashman, et al. (8). Savel'ev, et al, were the only investigators to analyze for all of the stable radiation products formed. They used dissolved ${ }^{210} \mathrm{Po}$ as a source of alpha particles for the radiolysis. Mahlman (gamma irradiation, ${ }^{60} \mathrm{Co}$ ) analyzed directly only for the hydrogen and oxygen yiclds and Vashman, ct al. (alpha irradiation, dissolved ${ }^{210} \mathrm{Po}$ ) examined only $\mathrm{OH}, \mathrm{NO}_{2}$ and $\mathrm{NO}_{3}$ radical formation in frozen nitric acid solutions by the electron paramagnetic resonance method.

One reason for the lack of information in nitric acid solutions is the difficulty of analysis of the radiolysis products. Nitrite and hydrogen peroxide are the major, stable, non-gaseous products. Nitrite, however, reacts with hydrogen peroxide in acid solutions. It also decomposes in acid solutions greater than $1 \mathrm{M}$. These reactions have to be prevented to obtain meaningful analytical results. This can be done by adding a reagent to the solutions which reacts with the nitrite when it is formed thus "protecting" it. $\mathrm{p}$-Nitroaniline was the reagent used in our work although other amines have also been used $(6,9)$. This nitrite protecting reaction presented problems in other analyses and in the interpretation of some radiolytic results, but it was necessary to obtain meaningful analytical results. Hydrogen peroxide could not be protected and consequently its yields were determined only in solutions of very low acid cuncentrations.

In acid solutions, the nitrite ion exists primarily as nitruus acid. But for brevity, "nitrite" will be used in the discussion that follows to represent any form of nitrite that is present.

In this study, nitric acid solutions of varying concentrations were gamma, alpha and beta irradiated.
Solutions that were alpha or beta irradiated were analyzed for nitrite only: solutions that were gamma irradiated were irradiated under a variety of conditions and analyzed for all stable products.

\section{SUMMARY}

Experimental Results: The radiolysis of nitric acid solutions was investigated with the goal of determining product yields and information on the mechanism of formation of these products.

Nitrite ion is the major radiolysis product. Its yield was determined as a function of nitric acid concentration for gamma, beta, and alpha irradiation. The nitrite yields for gamma and beta irradiation were found to be essentially the same. Although this similarity was expected, it did substantiate the unusual trend that was observed. The yields increased with increasing nitric acid concentration up to about $\mathrm{l} \mathrm{M}$, but then decreased. Previous investigations of neutral nitrate solutions had always shown an increase in yields at the higher nitrate concentrations.

The nitrite yields from alpha irradiation were appreciably lower than the yields from gamma and beta irradiations at lower acid concentrations, but continually increased with increasing nitric acid concentration. A possible mechanism, based on linearenergy-transfer (LET) effects on the following three radiolytic reactions, has been proposed to explain the difference in yields:

a) $\mathrm{H}_{2} \mathrm{O}-\left(\mathrm{H}, \mathrm{OH}, \mathrm{H}_{2}, \mathrm{H}_{2} \mathrm{O}_{2}\right)$

$\mathrm{H}+\mathrm{NO}_{3}^{-}-\mathrm{NO}_{2}+\mathrm{OH}^{-}$

b) $\mathrm{NO}_{3}^{-}-\mathrm{NO}_{2}^{-}+\mathrm{O}$

c) $\mathrm{HNO}_{3}-\mathrm{N}-\mathrm{NO}_{2}+\mathrm{OH}$

The first two reactions have been much used to explain the radiation chemistry of neutral nitrate solutions, whereas the direct radiolytic decomposition of $\mathrm{HNO}_{3}$ molecules, (c), is still open to question although there has been previous evidence for it. 
The effect of oxygen, acid concentration, and temperature on the nitrite yield from gamma irradiation was also determined. It was concluded that the presence of oxygen (air) or temperature variation had very little effect on the radiolysis. By irradiating solutions of varying acidity and constant nitrate concentration, it was verified that the acidity was responsible for the decrease in nitrite yields.

Hydrogen peroxide yields were also determined for gamma irradiation. Yield data were obtained only at low acid concentrations because hydrogen peroxide was destroyed by reaction with nitrite. The nitric acid concentration at which the net hydrogen peroxide yield became negligible coincided with the nitric acid concentration at which the nitrite production her.ame appreciable.

Gaseous products from gamma irradiation were determined by mass spectrometry. The only gas produced in greater than negligible yields, relative to nitrite and hydrogen peroxide, was oxygen at $10 \mathrm{M}$ nitric acid.

For evaluating the use of the microsphere form of plutonium oxide as an alpha source, information was required on the solubility of the microspheres in varying concentrations of nitric acid. This was determined for microspheres prepared by both the plasma torch process (Mound Laboratory) and the sol-gel process (Oak Ridge National Laboratory). The microspheres prepared by the plasma torch process were the least soluble of the two.

Unique Experimental Features: There were new or unique applications of materials and equipment in this program. The first was the use of plutonium, in the form of microspheres, as an alpha source. In the past, alpha irradiations have required either the dissolution of the alpha source in the material to be irradiated, with attendant problems of contamination, or the use of a specially designed external source whose efficiency, because of its design, was very low. The problems associated with both of these types of alpha sources were overcome by the use of the microspheres. They are inert and essentially insoluble and can be added directly to the solution so that their radiation can be used efficiently. When irradiation is complete, the microspheres can be removed, and the solution analyzed or treated in any other way desired. An irradiator was designed and constructed to contain the microspheres and irradiate the acid samples.
The beta source used for irradiation was obtained from a commercial supplier ( $3 \mathrm{M})$. It is a flow-through type of system, comparable in design to the alpha irradiating system. The beta particles used were from a ${ }^{90} \mathrm{Sr}-{ }^{90} \mathrm{Y}$ source. To our knowledge, this program was the first time this type of source had been used for irradiating liquids.

\section{MATERIALS AND METHODS}

Water from a Barnstead still was redistilled from a basic permanganate solution. It was then gamma irradiated in a quartz flask to destroy any remaining organic contaminants. The excess of hydrogen peroxide produced by the gamma irradiation was destroyed by UV irradiation ( $2537 \AA \mathrm{Hg}$ lamps). Glassware used for samples was cleaned by the same irradiation technique after first being washed with a nitric acid-dichromate solution.

The commercial nitric acid used was distilled in quartz equipment and oxygen was bubbled through the solution while heating $\left(\mathrm{ca} .70^{\circ} \mathrm{C}\right)$ to remove $\mathrm{NO}_{2}$. The p-nitroaniline was used as received from Eastman.

The nitrite ion concentration was determined colorimetrically by forming a $\mathrm{p}$-nitroaniline-azulene azo dye (10). A small fraction $\left(4 \cdot 10^{-3} \mathrm{M}\right)$ of the $p$-nitruatulinte was added prior to the irradiation to protect the nitrite when it was formed and afterward the full amount of p-nitroaniline and other reagents were added to develop the color. Hydrogen peroxide was analyzed by the titanium colorimetric method (11). The nitrite method had a relative error of $0.1 \%$ and the hydrogen peroxide $-2.1 \%$ in the range used. Gaseous products were analyzed by mass spectrometry. The results have an estimated relative error of $2 \%$.

Solutions were gamma irradiated in a Gammacell220 ,(B) a commercial gamma source containing 3800 curies of ${ }^{60} \mathrm{Co}$. The dose rate, as determined by Fricke dosimetry, was $3.6 \cdot 10^{17} \mathrm{eV} / \mathrm{ml} \cdot \mathrm{min}$. Repeated dosimetry runs had a relative standard deviation of less than one percent. Corrections were made, based on electron density, for additional energy absorption at the higher nitric acid concentrations. Irradiations in the presence of air were carried out in $12.5 \cdot 150 \mathrm{~mm}$ quartz test tubes. 
The nitric acid used to prepare these solutions was saturated with oxygen which was used to remove the $\mathrm{NO}_{2}$ and the water used contained excess oxygen from the decomposition of hydrogen peroxide. Oxygen was removed from solutions when required, by freezing (dry.ice) and thawing three times while the samples were attached to a vacuum line. These samples were contained in break-seal Pyrex tubes of approximately the same size as the quartz tubes.

Beta irradiations of aerated solutions were carried out in a Sr-90 Beta Irradiator manufactured by $3 \mathrm{M}$. It is a flow-through type apparatus. The source contained 500 curies of ${ }^{90} \mathrm{Sr}-{ }^{90} \mathrm{Y}$ packed around thin walled $(0.005 \mathrm{in}$.$) stainless steel tubes. The duse$ rate, determined by circulating $300 \mathrm{ml}$ of a Fricke solution, was $3.78 \cdot 10^{17} \mathrm{eV} / \mathrm{ml} \cdot \min$. Total irradiated volumes were always $300 \mathrm{ml}$; however, the actual volume in the irradiat or at any one time was $45 \mathrm{ml}$. It received a dose of $2.52 \cdot 10^{18}$ $\mathrm{eV} / \mathrm{ml} \cdot \mathrm{min}$. The same dose rate was used for all solutions on the assumption that essentially all the beta particles which entered the irradiation tubes were completely absorbed by the solution. This assumption is probably valid considering the geometry of the source, the beta energies, and the inside diameter of the tubes $(0.187 \mathrm{in}$.$) .$

Alpha irradiations of aerated solutions were carried out in a chamber (Figure 1) consisting of stainless steel tubes $\left(0.08\right.$ in. i.d.) filled with $70 \mathrm{~g}$ of $\mathrm{PuO}_{2}$ microspheres $\left(80\right.$ at. $\%{ }^{238} \mathrm{Pu}$ ). The micr uspheres, supplied through the AEC by Mound Laboratory, had diameters in the range of 60 to $260 \mu$. Quantitative information on the solubility of similar microspheres was determined in nitric acid of varying concentrations as discussed in the Appendix.. The microspheres were found to be inert and essentially insoluble in the nitric acid, as expected.

The alpha dose rate, determined by circulating $500 \mathrm{ml}$ of Fricke solution, was $1.07 \cdot 10^{18} \mathrm{eV} / \mathrm{ml} \cdot \mathrm{min}$., based on a $\mathrm{G}\left(\mathrm{Fe}^{+3}\right)$ of 5.1 (12). The total sample volume used in the iriradiatur was $500 \mathrm{ml}$. The duse rate within the irradiator tubes was approximately 100 times the above value, however, because only a small fraction of the total volume was being irradiated at any given time. It was assumed that all of the alpha particles emilted from the surface of the microsplieres were completely absurbed in the liquid layers between the microspheres, therefore no dose corrections were made for solutions of different acid strengths. If this assumption is not valid, the magnitude of the G-values obtained would decrease a maximum of approximately $25 \%$ in $10 \mathrm{M}$ nitric acid and corresponding lesser amounts at the lower acid concentrations; but the trend of the results would not be altered.

The convention used in this report is that $G(X)$ represents the final measured yield of product $X$ and $G_{X}$ represents the primary yield, i.e., the yield of product $\mathrm{X}$ as it emerges from the spur or track.

\section{RESULTS AND DISCUSSIONS}

\section{NITRITE YIELD}

\section{Effect of Nitric Acid Concentration:}

1. GAMMA RADIOLYSIS - Yield data for nitrite are given in Table I and Figure 2. These data show that in nitric acid below $1 \mathrm{M}$, the initial yields of nitrite increase with increasing acid concentration and a maximum concentration of nitrite is soon reached with an increase in dose. These are the same trends that have been observed in neutral solutions of nitrate at these concentrations (13). In the dilute acid solutions, where water is absorbing most of the radiant energy, the nitrite yield is determined by the reaction of the radicals formed from the radiolysis of water via the following mechanism (2).

$\mathrm{H}+\mathrm{NO}_{3}^{-} \rightarrow \mathrm{NO}_{2}+\mathrm{OH}^{-}$

$2 \mathrm{NO}_{2}+\mathrm{H}_{2} \mathrm{O} \rightarrow \mathrm{NO}_{2}^{-}+\mathrm{NO}_{3}^{-}+2 \mathrm{H}^{+}$

$\mathrm{OH}+\mathrm{NO}_{2}^{-} \rightarrow \mathrm{NO}_{2}+\mathrm{OH}^{-}$

The increase in nitrite yield with increasing nitrate concentration is consistent with the mechanism although it may be an oversimplification because the $\mathrm{N}(\mathrm{IV})$ species may not necessarily be $\mathrm{NO}_{3}(5)$.

Although the nitrite produced in nitric acid concentrations of $1 \mathrm{M}$ and greater increased linearly over the dose range investigated, further irradiation could eventually lead to a leveling of the yield. One experiment with $1 \mathrm{M}$ nitric acid actually showed a slight decrease in nitrite concentration at doses greater than $10^{19} \mathrm{eV} / \mathrm{ml}$. It could not be determined, however, whether this was caused by the decomposition of nitrite, the p-nitroaniline, or the diazo compound formed to protect the nitrite. 


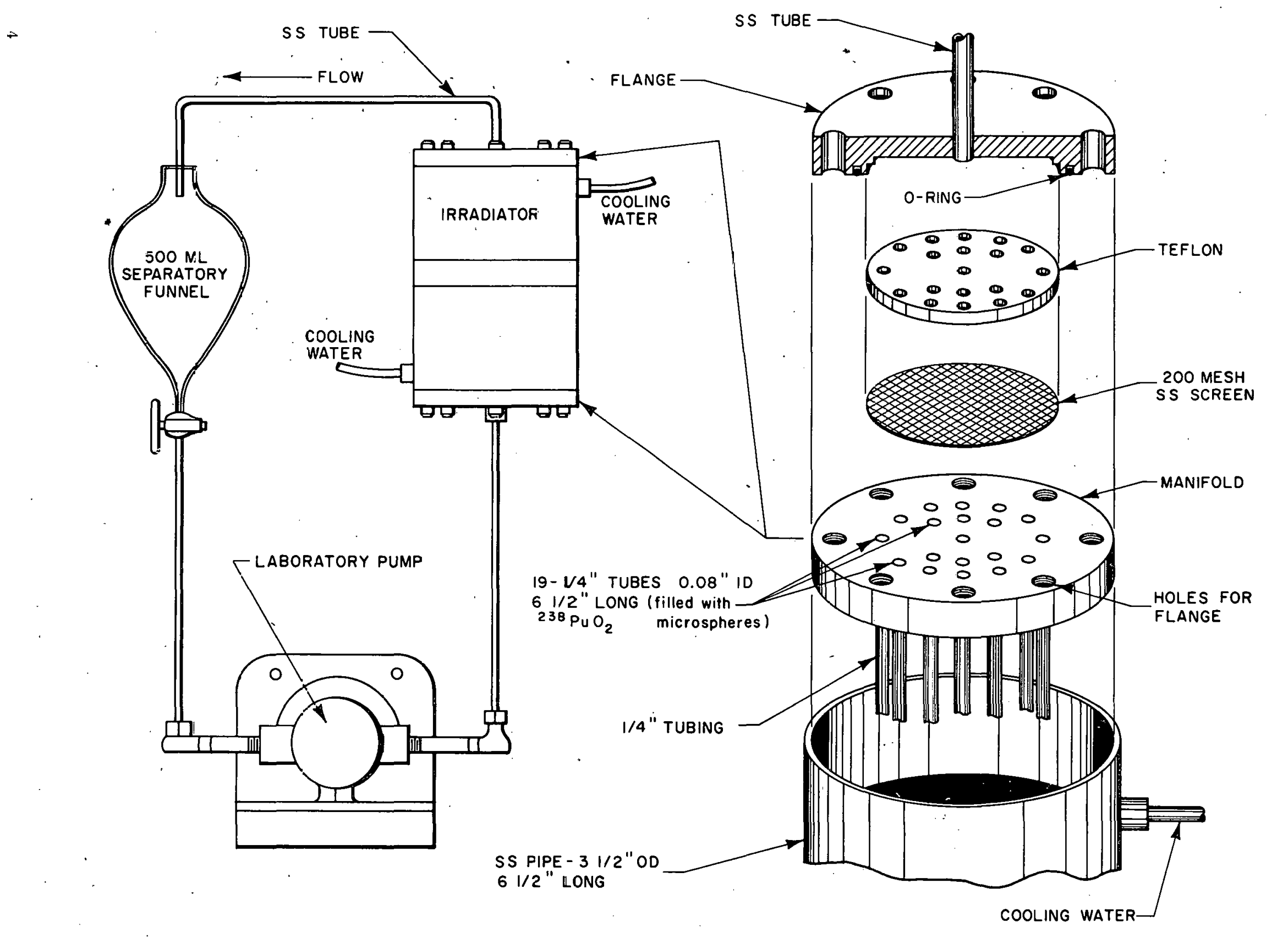




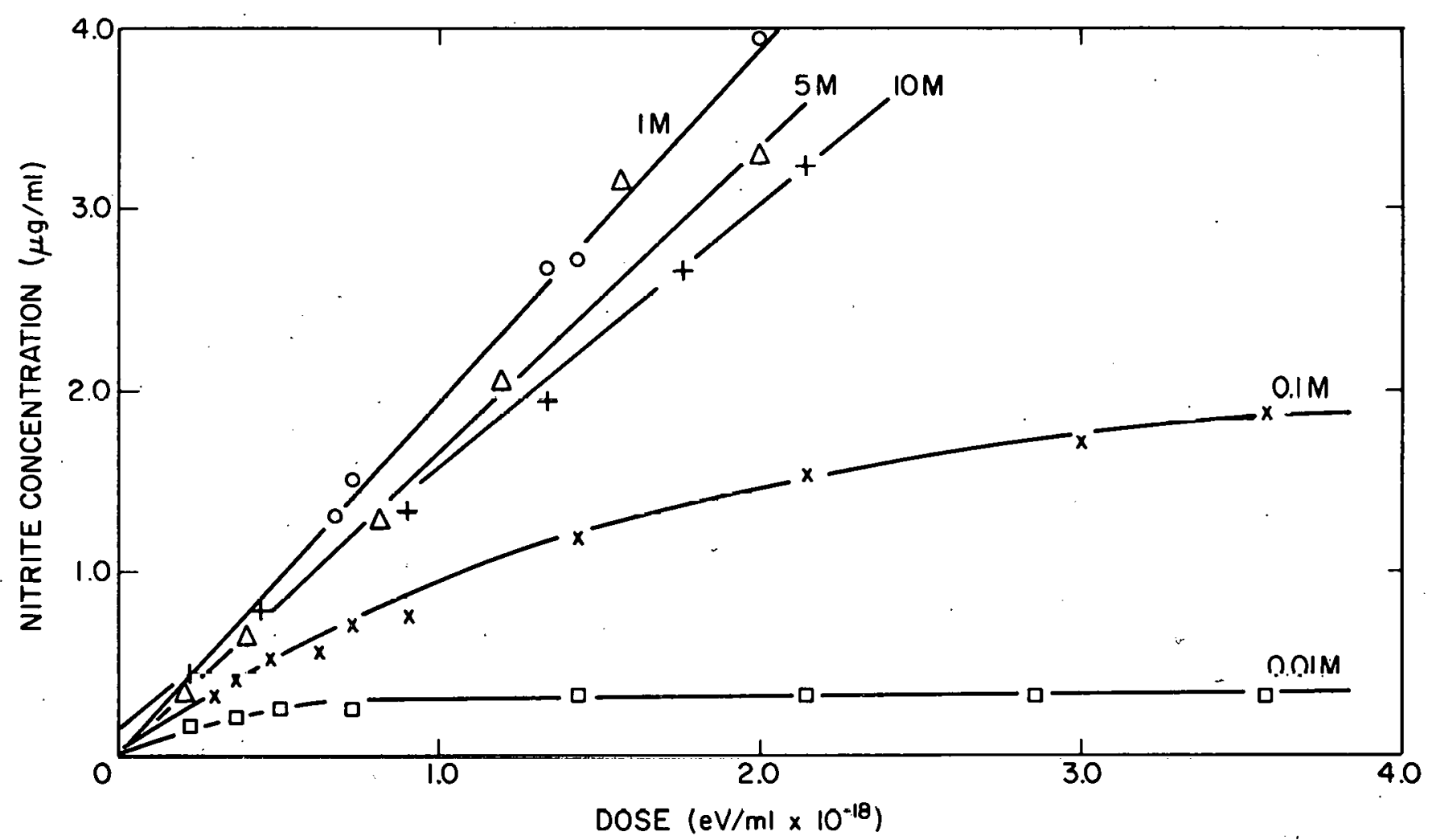

Figure 2. Nitrite yield, gamma irradiation.

Table I. Nitrite and hydrogen peroxide yields.

Gamma Irradiation

$$
\mathrm{G}\left(\mathrm{NO}_{2}^{-}\right)^{*}
$$

\begin{tabular}{cccc}
$\mathrm{HNO}_{3}$ conc., M & In air & In vacuum & $\begin{array}{c}\text { Max. } \mathrm{NO}_{2}^{-} \text {conc., } \\
\mu \mathrm{g} / \mathrm{ml}\end{array}$ \\
\cline { 1 - 1 } 0.01 & 1.6 & - & 0.3 \\
0.1 & 1.6 & 1.3 & 2.0 \\
1 & 2.6 & 2.0 & - \\
5 & 2.2 & 2.2 & - \\
10 & 1.9 & 2.1 & -
\end{tabular}

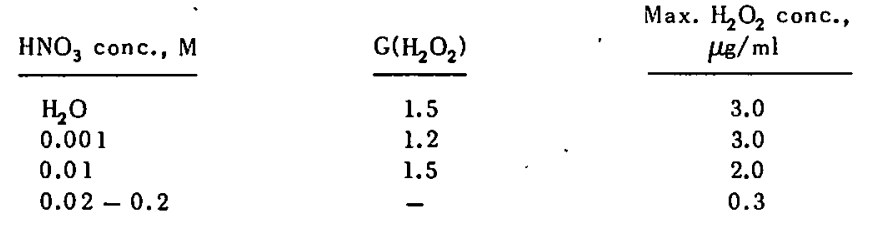

*G-value $=$ number of molecules formed per $100 \mathrm{eV}$ of absorbed energy.

Table I.also shows an unexpected decrease in the nitrite yield with an increase in the nitric acid concentration above $1 \mathrm{M}$. This is contrary to an expected increase in nitrite $\cdot \dot{w i t h}$ increasing nitrate concentration as experienced in neutral solutions (3). In the past, in order to account for increasing nitrite production with increasing nitrate ion concentration in neutral solutions (5), it was necessary to invoke a "direct" radiation effect to supplement the "indirect" effect represented by reactions 1 through 3 . This direct effect has been represented as:

$\mathrm{NO}_{3}^{-} \rightarrow \mathrm{NO}_{2}^{-}+0$

Daniels (5) has calculated the $\mathrm{G}\left(\mathrm{NO}_{2}^{-}\right)$contribution from this effect to be 4.0 .

A possible mechanism to explain the observed decrease in nitrite yield with an increase in nitric acid above $1 \mathrm{M}$ will be discussed later.

2. BETA RADIOLYSIS - The nitrite yield data for beta radiolysis, shown in Table II and Figure 3, are essentially the same as the data for gamma radiolysis. This is expected since the radiolytic 


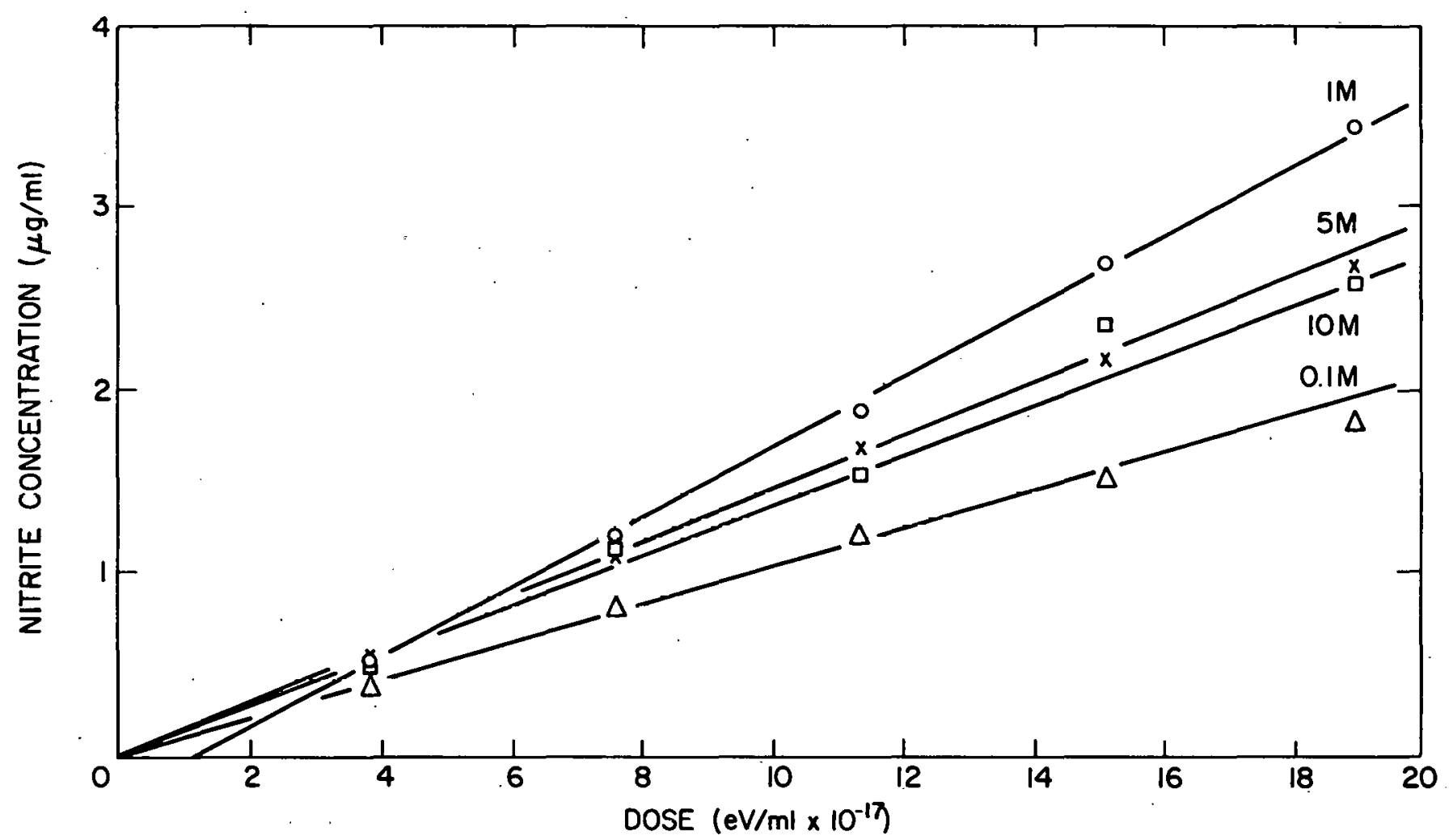

Figure 3. Nitrite yield, beta irradiation.

mechanism is the same for high energy beta irradiation as for gamma irradiation. The importance of the beta radiolysis results is that they substantiate the unexpected decrease in nitrite yield with increasing nitric acid concentrations that was obtained from gamma irradiation.

The beta results were obtained using a flow system for irradiation instead of the static system used in gamma radiolysis. A comparable flow system was also used for the alpha irradiations.

Table II. Nitrite Yields.

\begin{tabular}{|c|c|c|c|}
\hline $\mathrm{HNO}_{3}$ conc., $\mathrm{M}$ & $\begin{array}{c}\text { Alpha } \\
\text { Irradiation }\end{array}$ & $\begin{array}{c}\text { Beta } \\
\text { Irradiation }\end{array}$ & $\begin{array}{c}\text { Ganima } \\
\text { Irradiation }\end{array}$ \\
\hline 0.1 & 0.51 & 1.4 & 1.6 \\
\hline 1 & 1.3 & 2.5 & 2.6 \\
\hline 5 & 1.8 & 1.9 & 2.2 \\
\hline 10 & 2.8 & 1.8 & 1.9 \\
\hline
\end{tabular}

3. ALPHA RADIOLYSIS - The nitrite yields from alpha irradiation are shown in Table II and Figure 4. These yields are essentially the same as those reported by Savel'ev, et al, (6) who used a dissolved alpha source instead of a solid source such as we used. The data shows that the nitrite yields from alpha irradiation are appreciably lower than the yields from the gamma (or beta) irradiations at lower acid concentrations, but continually increase with increasing nitric acid concentrations.

\section{MECHANISM OF NITRITE FORMATION - We} have developed an explanation for the differences in alpha and gamma (or beta) yields of nitrite. This explanation is based on the difference in LET (linear-energy-transfer) of the radiation used and the effect this difference has on the three postulated reactions that are involyed in the radiolysis of nitric acid.

The differences in the LET of the radiation used for irradiating nitric acid are apparent from the data 


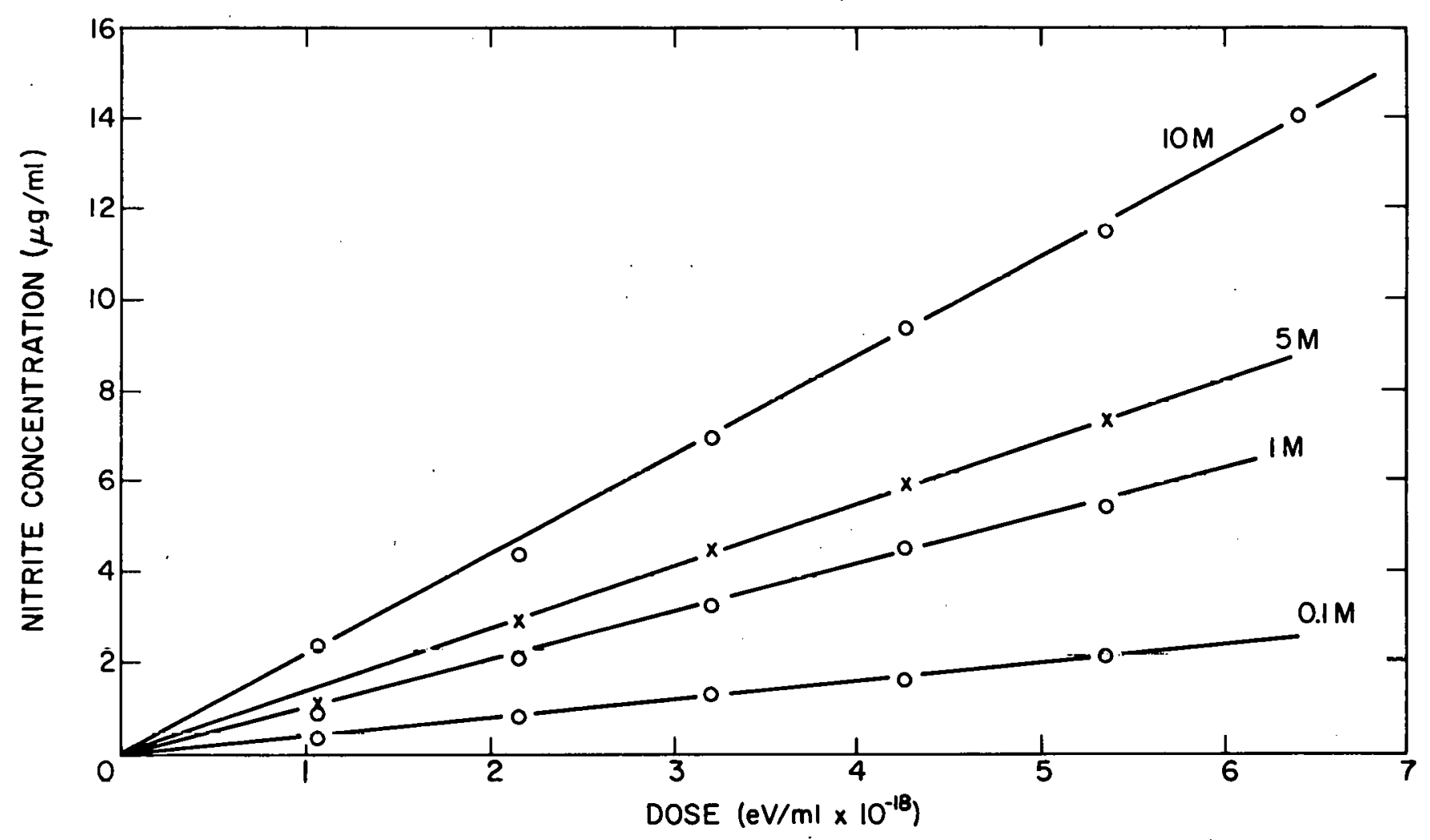

Figure 4. Nitrite yield, alpha irradiation.

in Table III which is adapted from Spinks and Woods (14).

Table III. LET values.

\begin{tabular}{|c|c|c|c|}
\hline $\begin{array}{l}\text { Particle or } \\
\text { radiation }\end{array}$ & Source & Energy, meV & $\begin{array}{c}\mathrm{LET} \text { in } \mathrm{H}_{2} \mathrm{O} \\
\mathrm{ke} V / \mu\end{array}$ \\
\hline gamma & ${ }^{60} \mathrm{Co}$ & 1.25 & 0.27 \\
\hline \multirow[t]{2}{*}{ beta } & ${ }^{90} \mathrm{Sr}$ & 6.54 & 0.27 \\
\hline & ${ }^{90} \mathrm{Y}$ & 2.25 & 0.20 \\
\hline \multirow[t]{3}{*}{ alpha } & ${ }^{210} \mathrm{Po}$ & 5.30 & 136.0 \\
\hline & ${ }^{238} \mathrm{Pu}$ & 5.49 & - \\
\hline & ${ }^{239} \mathrm{Pu}$ & 5.16 & - \\
\hline
\end{tabular}

The three radiolytic reactions involved in the radiolysis of nitric acid are as follows:

a. Indirect effect

$\mathrm{H}_{2} \mathrm{O} \longrightarrow\left(\mathrm{H}, \mathrm{OH}, \mathrm{H}_{2}, \mathrm{H}_{2} \mathrm{O}_{2}\right)$

$\mathrm{H}+\mathrm{NO}_{3}^{-} \rightarrow \mathrm{NO}_{2}+\mathrm{OH}^{-}$

The LET effects on the decomposition of water are known and yiclds for the products in solution al pH 0.5 have been summarized by Spinks and Woods (14) as follows:
$\mathrm{G}_{\mathrm{H}} \quad \mathrm{G}_{\mathrm{OH}} \quad \mathrm{G}_{\mathrm{H}_{2}} \quad \mathrm{G}_{\mathrm{H}_{2} \mathrm{O}_{2}} \quad \mathrm{G}_{-\mathrm{H}_{2} \mathrm{O}}$

$\begin{array}{llllll}\text { gamma radiation } & 3.70 & 2.90 & 0.40 & 0.80 & 4.5\end{array}$

$\begin{array}{llllll}\text { alpha radiation } & 0.60 & 0.50 & 1.57 & 1.45 & 3.6\end{array}$

At nitric acid concentrations less than $1 \mathrm{M}$, the difference in yields between alpha and gamma (or beta) irradiation can be attributed to the difference in yields from water radiolysis. The nitrite yield from gamma (or beta) irradiation is larger than the yield from alpha irradiations because of the larger yield of $\mathrm{H}$ from the gamma (or beta) radiolysis of water. This difference predominates through $5 \mathrm{M}$ nitric acid.

In $0.1 \mathrm{M}$ nitric acid, the nitrite yield leveled off with increasing dose for gamma (and also for beta, although Figure 3 is not extended far enough to show this) but not for alpha irradiation. Hyder (2) and Pikaev, et al, (13) experienced a similar decrease in yields with irradiation dose with gamma or accelerated electrons.

The most obvious back reaction to account for this leveling of yield is: 
$\mathrm{H}+\mathrm{H}_{2} \mathrm{O}_{2} \rightarrow \mathrm{H}_{2} \mathrm{O}+\mathrm{OH}$

This would decrease the nitrite yield by decreasing the $\mathrm{H}$ concentration and increasing the $\mathrm{OH}$ concentration. However, it is not clear why the same reaction would not take place in alpha irradiated solutions since alpha irradiation produced hydrogen peroxide at a faster rate than does gamma irradiation.

b. Direct effect - nitrate ion

$\mathrm{NO}_{3}^{-} \leadsto \mathrm{NO}_{2}^{-}+\mathrm{O}$

This reaction has been much used (5) to account for the continual increase in nitrite yields as nitrate concentrations are increased above $1 \mathrm{M}$. A direct decomposition must be invoked because a significant fraction of the radiative energy is absorbed by the $\mathrm{NO}_{3}{ }^{-}$(or $\mathrm{HNO}_{3}$ ); $26 \%$ and $48 \%$ at 5 and $10 \mathrm{M}$ nitric acid, respectively.

By analogy to water, a LET effect could also exist for reaction 4 . In water radiolysis, the difference in $\mathrm{G}_{-\mathrm{H}_{2} \mathrm{O}}$ for alpha and gamma radiolysis is not very large, but the difference in molecular and radical yields is quite significant. In reaction 4 , the only possibility for radical combination within a spur or track would be combination of oxygen atoms to produce molecular oxygen; there would be no reaction between the nitrite ions. If an LET effect did exist, it is expected that $G_{0}$ would be higher and $G_{O_{2}}$ lower for gamma (or beta) irradiation than for alpha irradiation. The oxygen molecule would not affect the yields whereas the oxygen atom can increase the nitrite yield by reducing nitrate ion concentration (reaction 6). The higher nitrite yields from gamma

$\mathrm{O}+\mathrm{NO}_{3}^{-} \rightarrow \mathrm{NO}_{2}^{-}+\mathrm{O}_{2}$

(or beta) irradiation, particularly at $5 \mathrm{M}$ nitric acid, could be due, in part, to reactions 4 and 6 .

c. Direct effect - nitric acıd molecule

$\mathrm{HNO}_{3} \simeq \mathrm{NO}_{2}+\mathrm{OH}$

Undissociated nitric acid molecules can undergo radiolytic decomposition (reaction 7) just like the nitrate ion. This reaction has been suggested by Mahlman (7) and Vashman, et al, (8). In both cases, the OH radical yield was measured and found to increase with increasing acid concentration, thus verifying reaction 7. Mahlman's results were obtained indirectly using thallous ion as an $\mathrm{OH}$ scavenger, while Vashman, et al, made EPR measurements of frozen nitric acid solutions.

To assess the possible importance of reaction 7 , information on the degree of dissociation of nitric acid is necessary. Redlich, et al, (15), using proton magnetic resonance, determined that the fraction of undissociated nitric acid varies from $1 \%$ in $1 \mathrm{M}$ nitric acid to $48 \%$ in $10 \mathrm{M}$ acid.

Once again, the yields of the radical products would be expected to be higher for gamma irradiation because of the LET difference. Radical combination would be higher for alpha irradiation, producing a higher hydrogen peroxide yield. $\mathrm{N}_{2} \mathrm{O}_{4}$ might also be produced, but it reverts to $\mathrm{NO}_{2}$.

At $10 \mathrm{M}$ nitric acid, where $48 \%$ of the acid molecules are undissociated, reaction 7 would become quite significant. In this reaction an oxidizing radical, $\mathrm{OH}$, is produced in contrast to the reducing radical $(0)$ in reaction 4 . If $\mathrm{NO}_{2}$ and $\mathrm{OH}$ react according to reactions 2 and 3 , there would be no net yield of nitrite; and if gamma (or beta) irradiation produces a preponderance of radicals, the overall nitrite yield would be decreased by a mechanism involving reactions 2 and 3 . If alpha irradiation produced primarily molecular products, the nitrite yield would be increased because the hydrogen peroxide formed would have no effect.

Thus, on the basis of the above reactions and the effect of LET on these reactions, one can qualitatively account for the experimental differences of nitrite yield between alpha and gamma (or beta) irradiations. A more rigorous evaluation of the overall mechanism would require other information, such as kinetic data, which is not currently available.

The effect of dose rate on the nitrate yield in neutral nitrate solution has been investigated by Pikaev, et al, (13). They found that an increase in dose rate increased the nitrite yield, but nnly in dilute solutions: at $\mathrm{l} \mathrm{M}$ sodium nitrate, no increase in yield with increased dose rate was observed. The increase in yield at the low concentrations was attributed to the reaction $\mathrm{OH}+\mathrm{OH} \rightarrow \mathrm{H}_{2} \mathrm{O}_{2}$ taking precedence over the reaction $\mathrm{OH}+\mathrm{NO}_{2}^{-} \rightarrow \mathrm{NO}_{2}+\mathrm{OH}^{-}$. By using pulse radiolysis, Pikaev, et al, were able to 
vary the dose rate dramatically $\left(3.6 \cdot 10^{17}\right.$ to $\left.6 \cdot 10^{24} \mathrm{eV} / \mathrm{ml} \cdot \mathrm{min}\right)$. The fact that no dose rate effect was observed by Pikaev, et al, on nitrite yields, except at nitrate concentrations less than $1 \mathrm{M}$, lends credence to assigning the increase in nitrite yield observed in our experimental work to a LET difference between alpha and gamma (or. beta) and not to a difference in dose rates between these irradiations.

Effect of Oxygen: Nitrite yields were also determined by gamma irradiation of en vacuo nitric acid solutions. The results are shown in Table $I$. Oxygen in air can decrease the nitrite yield by reacling with $\mathrm{H}$ (reaction 8 ) and thereby preventing reaction 1.

\begin{tabular}{lc}
\multicolumn{1}{c}{ Reaction } & $\begin{array}{c}\text { Approx. rate constant, } \\
\mathrm{M}^{-1} \text { sec. }\end{array}$ \\
\hline $\begin{array}{l}\mathrm{H}+\mathrm{O}_{2} \rightarrow \mathrm{HO}_{2} \\
\mathrm{H}+\mathrm{NO}_{3} \rightarrow \mathrm{NO}_{2}+\mathrm{OH}^{-}\end{array}$ & $10^{10}$ \\
& $10^{7}$
\end{tabular}

Since the oxygen concentration in air-saturated water is $3 \cdot 10^{-4} \mathrm{M}$, it is expected, on the basis of the rate constants of the above reactions, that the oxygen would scavenge the $\mathrm{H}$ only at nitric acid concentrations of less than $0.1 \mathrm{M}$, leading to a decrease in the nitrite yields. Instead, the reverse of this effect is observed at $0.1 \mathrm{M}$ nitric acid and even at $l \mathrm{M}$, where there should be no effect. Most previous investigations have shown that oxygen has little or no effect on the nitrite yield (3). However, Hyder (2) obtained a very large decrease in nitrite yield for oxygen saturated sodium nitrate solutions which he attributed to the reoxidation of the intermediate $\mathrm{NO}_{2 \mathrm{aq}}$.

Effect of Acidity: Solutions of varying acidity and constant nitrate concentrations (prepared using sodium nitrate) were gamma irradiated. The nitrite yields from $5 \mathrm{M}$ nitrate were determined as a function of dose. One yield was also determined at $8 \mathrm{M}$ nitrate. The results, shown in Figure 5, indicate that the acidity is responsible

Figure 5. Nitrite yield, gamma irradiation - effect of acidity.

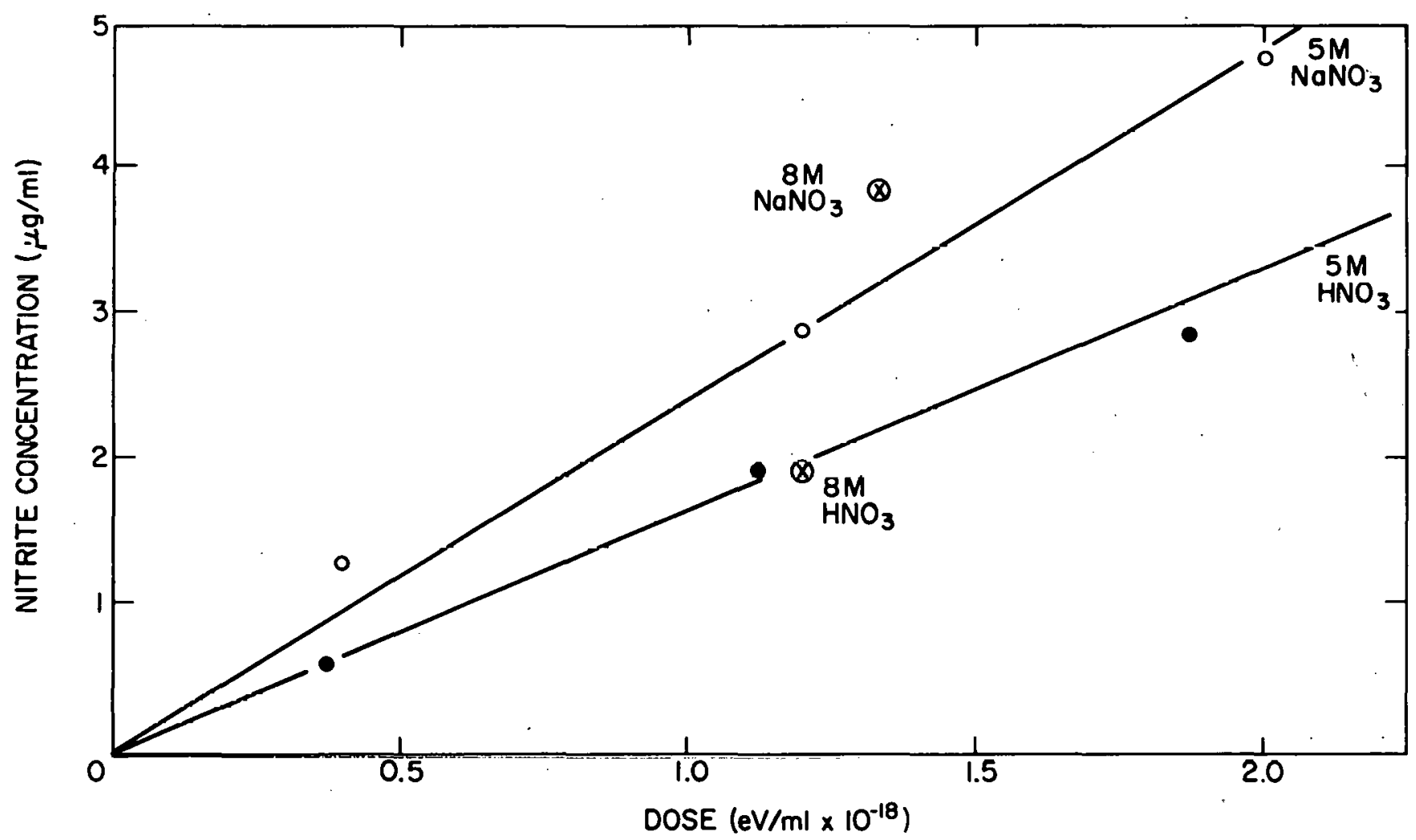


for the decrease in nitrite yields. The yields would continue to increase with nitrate concentration if neutral salt solutions were irradiated.

Effect of Temperature: One molar nitric acid solutions were gamma irradiated at $80^{\circ} \mathrm{C}$ and the nitrite yields were found to be somewhat scattered and non-linear with increasing dose. The nitrite yields were slightly lower than yields at room temperature for low doses and considerably lower at higher doses. Experiments with standard nitrite solutions containing p-nitroaniline indicated that the diazonium salt formed to protect the nitrite is somewhat unstable at $80^{\circ} \mathrm{C}$. This would account for the lower yields. With this explanation for the lower yields, and with the yields at room temperature and $80^{\circ} \mathrm{C}$ being relatively close at the shorter irradiation times, it was concluded that there was very little, if any difference between the yields at $80^{\circ} \mathrm{C}$ and those at room temperature.

Hydrogen Peroxide Yield: In acid solution, hydrogen peroxide reacts with nitrite according to $\mathrm{H}_{2} \mathrm{O}_{2}+\mathrm{HNO}_{2} \rightarrow \mathrm{HNO}_{3}+\mathrm{H}_{2} \mathrm{O}$. This reaction is rapid in strongly acid solutions, but appreciably slower in weakly acid ( $\mathrm{pH} 4)$ or neutral solutions (16). To insure that the reaction was always complete prior to analysis, all irradiated samples were made $\mathrm{l} \mathrm{M}$ in sulfuric acid and allowed to stand for 2 minutes before the determination of their hydrogen peroxide content. Experiments with standard solutions demonstrated that these conditions were adequate to ensure the completion of the reaction. Thus, all hydrogen peroxide yields are net yields, i.e., the amount of hydrogen peroxide remaining after reaction with all of the nitrite present.

The colorimetric method for hydrogen peroxide could not be used in the presence of p-nitroaniline (the spectra of the peroxy-titanium compound overlaps that of the p-nitroaniline) so it was not possible to determine gross hydrogen peroxide yields by forming a diazo compound with nitrite to prevent its reaction with hydrogen peroxide.

The "pooled" standard deviation of replicate hydrogen peroxide runs over the concentration range investigated was 0.03 . The hydrogen peroxide yields were extremely sensitive to impurities in the solution and the elaborate process for the purification of water described above was necessary to obtain consistent results. In some cases even this process ivas ineffective and these batches of water could not be used.
Yield data for hydrogen peroxide are presented in Table I. The G-values were calculated using the initial section of a non-linear curve. Because of the large variations inherent in this procedure, the G-values in the dilute nitric acid solutions cannot be considered different from that of water. As in water, back reactions such as:

$\mathrm{H}+\mathrm{H}_{2} \mathrm{O}_{2} \rightarrow \mathrm{H}_{2} \mathrm{O}+\mathrm{OH}$

$\mathrm{OH}+\mathrm{H}_{2} \rightarrow \mathrm{H}_{2} \mathrm{O}+\mathrm{H}$

appear very early and the yield curves plateau at $2-3 \mu \mathrm{g} \mathrm{H}_{2} \mathrm{O}_{2} / \mathrm{ml}$. These are the maximum concentrations listed in the table. At greater acid concentrations $(0.02-0.2 \mathrm{M})$, low hydrogen peroxide concentrations of approximately $0.3 \mu \mathrm{g} \mathrm{H}_{2} \mathrm{O}_{2} / \mathrm{ml}$ were always obtained but with very poor reproducibility. $S$ ince this is the nitric acid concentration range at which the nitrite yields begin to become appreciable, the hydrogen peroxide concentration is reduced because it or its precursor, $\mathrm{OH}$, is reacting with nitrite.

Gaseous Yields: Nitric acid solutions were gamma irradiated in a vacuum and the gaseous products analyzed by mass spectrometry. p-nitroaniline was not added to these solutions. The average $G$-values of the predominant species are given in Table IV. The yields were determined over a dose range and appeared to be constant except for the $\mathrm{O}_{2}$ yield at io $\mathrm{M} \mathrm{HNO}_{3}$. The results are in general agreement with previous work $(6,7)$ and can be explained qualitatively on the basis of the scheme used to describe the radiation chemistry of nitrate solutions. The hydrogen yield would be expected to decrease with increasing acid concentration because the water fraction is decreasing. The oxygen yield would be expected to increase with acid concentration because of the increase in the direct effect, reaction 4.

The only gas produced in greater than negligible yields, relative to nitrite and hydrogen peroxide, is oxygen and only at $10 \mathrm{M}$ nitric acid. There was a large variation in the oxygen analyses, varying from $G=0.2$ to $G=0.9$. The particular value depended on the duration of the irradiation and the time between irradiation and analysis. Apparently, oxygen is involved in a relatively slow back reaction. A G of 0.7 was selected as a fairly reliable result.

The increase in $\mathrm{G}\left(\mathrm{O}_{2}\right)$ with increasing acid concentration is consistent with the results obtained on both the alpha radiolysis (6) and the gamma 
radiolysis (7) of nitric acid. It is not in agreement with the work of Sheppard (17) where, with alpha radiolyse's, he found a decrease of $\mathrm{G}\left(\mathrm{O}_{2}\right)$ with an increase in nitric acid concentration.

Table IV. Gaseous products yield.

\begin{tabular}{|c|c|c|c|}
\hline \multirow[b]{2}{*}{ Product } & \multicolumn{3}{|c|}{$G$ (product) } \\
\hline & $0.1 \cdot \mathrm{M} \mathrm{HNO}_{3}$ & $1 \mathrm{M} \mathrm{HNO}_{3}$ & $10 \mathrm{M} \mathrm{HNO}_{3}$ \\
\hline $\mathrm{O}_{2}$ & 0.01 & 0.04 & 0.70 \\
\hline $\mathrm{H}_{2}$ & 0.08 & 0.05 & 0.01 \\
\hline $\mathrm{N}_{2}$ & 0.004 & 0.007 & 0.006 \\
\hline NO & Trace & .0 .002 & 0.003 \\
\hline Total gas & 0.11 & 0.11 & 0.8 \\
\hline
\end{tabular}

\section{LITERATURE CITED}

1. A. K. Pikaev, The Radiation Chemistry of Aqueous Solution of Inorganic Nitrogen Compounds, Russ. Chem. Rev. 29 235-243 (1960).

2. M. L. Hyder, The Radiolysis of Aqueous Nitrate Solutions, J. Phys. Chem 69 1858-1865 (1965).

3. M. Daniels and E. E. Wigg, Radiation Chemistry of the Aqueous Nitrate System, J. Phys. Chem. 71 1024-1033 (1967).

4. F. J. Miner and J. R. Seed, Radiation Chemistry of Plutonium Nitrate Solutions, Chem. Rev. 67 . 299-315 (1967).

5. M. Daniels, Radiation Chemistry, I, R. F. Gould, ed., Adv. in Chemistry, Vol 81, 153-163, American Chemical Society, Washington, D. C., 1968.

6. Yu. I. Savel'ev, Z. V. Ershova, and M. V. Vladimirova, Alpha-radiolysis of Aque ous Solutions of Nitric Acid. Soviet Radiochemistry 9 221-225 (1967).

7. H. A. Mahlman, The $\mathrm{OH}$ Yield in the Co-60 $\gamma$ Radiolyses of $\mathrm{HNO}_{3}$, J. Chem. Phys. 35 936-939 (1961).

8. A. A. Vashman, Yu. I. Sável'ev and M. V. Vladimirova, EPR Investigation of Intermediate Products of Alpha-Radiolyses of Aque ous Solutions of Nitric Acid, Soviet Radiochemistry 9 344-347 (1967).

9. A. M. Kabakchi, V. A. Gramolin, V. M. Erokhin, Some Data on the Effect of Ionizing Radiation on
Concentrated Aqueous Solutions of Inorganic Salts, Proceedings of the First All-Union Conference on Radiation Chemistry, 45-48 (1958).

10. E. E. Garcia, Determination of Nitrite Ion Using the Reaction with p-nitroaniline and Azulene, Anal. Chem. 39 1605-1607 (1967).

11. A. C. Egerton, A. J. Eiverett, G. J. Minkoff, S. Rudrakanchana, and K: C. Salooja, The Analyses of Combustion Products. I. Some Improvements in the Methods of Analyses of Peroxides, Anal. Chim. Acta 10 422-428 (1954).

12. C. N. Trumbore and E. J. Hart, $a$-Radiation of Ferrous Sulfate in $0.4 \mathrm{M}$ Sulfuric Acid Solutions, J. Phys. Chem. 63 867-873 (1959).

13. A. K. Pikaev, P. Yu Glazunov and A. A. Kabubovich, Radiolysis of Neutral Nitrate Solutions at High Dose Rates, Kinetics Catalyses (USSR) 4 735-741 (1963).

14. J. W. T. Spinks and R. J. Woods, An Introduction to Radiation Chemistry, John Wiley and Sons, New York, 1964.

15. O. Redlich, R. W. Duerst, and A. Merbach, Ionization of Strong Electrolytes. XI. The Molecular States of Nitric Acid and Perchloric Acid, J. Chem. Phys. 49 2986-2994 (1968).

16. E. Halfpenny and P. L. Robinson, Pernitrous Acid. The Reaction between Hydrogen Peroxide and Nitrous Acid, and the Properties of an Intermediate Product, J. Chem. Soc. 1952 928-938.

17. J. C. Sheppard, Alpha Radiolysis of Plutonium (VI)- Nitric Acid Solutions. U. S. Atomic Energy Commission Report BNWL-751. May 1968

\section{APPENDIX}

In planning for the alpha irradiation work, information was required on the solubility of plutonium oxide microspheres in nitric acid solutions up to $10 \mathrm{M}$ in concentration. No nitric acid solubility data was available in the literature or from those sites that are manufacturing microspheres. It was necessary, therefore, to obtain this data experimentally. 
RFP-1299

Solubility data were obtained on microspheres prepared by both the plasma torch process (from Mound Laboratory) and the sol-gel process (from Oak Ridge National Laboratory). The microspheres used for these solubility determinations were prepared from plutonium whose major isotope was ${ }^{239} \mathrm{Pu}$. For the investigations of the alpha irradiations of nitric acid, microspheres that had a high ${ }^{238} \mathrm{Pu}$ content were used because of their higher alpha flux.

The microspheres, as received, contained "fines" and surface contamination which was necessary to remove before determining solubility. A circulating system, which pumped acid continuously over approximately a $1 \mathrm{~g}$ sample of microspheres, was used both for cleaning and for determining the solubility of the microspheres.

The circulating system consisted of a pump in series with a glass reservoir and a $0.5 \mu$ Millipore (B) filter. Acid solutions were pumped over the sample for predetermined periods of time. Then the circulating solution and the particulate material on the Millipore filter were analyzed. It was found that 8 hours were required, using $7 \mathrm{M}$ nitric acid containing a wetting agent, to clean the microspheres to a constant, low level of activity in the wash solution.

Using the cleaned microspheres, solubilities were determined. The data obtained is shown in the following table:

Solubility of microspheres in nitric acid.

$$
\begin{aligned}
& \text { Average Solubility } \\
& \mu \mathrm{g} \mathrm{Pu} \cdot \mathrm{day}^{-1} \cdot \mathrm{m}^{2}
\end{aligned}
$$

$\mathrm{HNO}_{3}$ conc., $\mathrm{M}$

Plasma torch

Sol-gel

1
3
5
7
9
10

The plasma-torch prepared material is less soluble than the sol-gel material probably because it is subjected to higher temperatures during preparation. 